\title{
MODEL COLLABORATIVE GOVERNANCE DALAM PEMBANGUNAN DESA PADA MASA COVID-19: STUDI DI KABUPATEN LAMPUNG SELATAN
}

\author{
Ardian Prabowo ${ }^{1}$, M. R. Khairul Muluk ${ }^{2}$, Ainul Hayat ${ }^{3}$ \\ 1,2,3 Fakultas Ilmu Administrasi, Universitas Brawijaya \\ $\left.{ }^{*}\right)$ Korespondensi: ardianprabowo11@gmail.com
}

\begin{abstract}
At present, the Covid-19 contagious disease outbreak can spread rapidly throughout the world, including Indonesia. Apart from having a negative impact on the health sector, it also impacts the economic, social, cultural, resilience, tourism and other sectors. This can threaten people in rural areas who have gaps in health accessibility and high levels of poverty compared to urban areas. So it is necessary to carry out village economic development, but still protect the health of rural communities from the Covid-19 disaster. This cannot be done by the government alone. Interdisciplinary and field cooperation is required by referring to the principles of collaborative governance. The research objective was to determine the ideal collaborative governance model in village development during the Covid-19 pandemic. This research uses qualitative methods with a descriptive approach. This method can be studied comprehensively and deeply. The results of this study indicate that in South Lampung Regency there are already several priority

Article Histori:

Accepted: 2/2/2021

Review: 30/3/2021

Publish: 30/4/2021 activities in the economic and health sectors, some of these priority activities such as Covid-19 Response Village, Village Cash Intensive Work, Village Fund Direct Cash Assistance (BLT), and other Infrastructure Development. These priority activities are collaborations carried out by the government, society and business.
\end{abstract}

Keyword: Collaborative Governance, Village Development, Covid-19.

\section{PENDAHULUAN}

Pada tanggal 11 Maret 2020, telah diumumkan COVID-19 sebagai pandemic global oleh Jendral World Health Organization (WHO) yang berarti wabah penyakit menular menyebar ke seluruh dunia. Hal tersebut didorong oleh kecepatan yang kita gunakan melintasi perbatasan negara dan benua. Penyebaran dari COVID-
19 keseluruh negara di dunia. Mengutip data dari The Center for Systems Science and Engineering Johns Hopkins University (2020) pada tanggal 23 Agustus 2020, terdapat jumlah masyarakat yang positif dari COVID-19 mencapai 23.357.435 orang. Data tersebut dapat berkembang setiap harinya. Covid-19 berdampak pada perekonomian dunia yang semakin 
meningkat. Sehingga pandemik ini akan membuat perekonomian dunia hilang + US\$ 1 triliun dan pertumbuhan ekonomi dunia di bawah $2 \%$, jauh di bawah prediksi sebelumnya yang mencapai 2,5\% (World Bank, 2020). Hal tersebut berdampak pada roda perekonomian dunia, termasuk Indonesia. Covid-19 bisa memengaruhi laju aktivitas sehari-hari masyarakat, termasuk di sektor ekonomi. Dampak yang terlihat pada sektor riil langsung seperti pekerja hotel, industi manuaktur, dan lain sebagainya berakhir pada PHK bagi pekerja (Iswara, 2020; Amindoni, 2020). Selain itu, pandemic ini berdampak kepada para pedagang, terutama sejak imbauan pembatasan mobilitas. Pusat-pusat perbelanjaan mulai sepi pengunjung akibat kekhawatiran tertular virus corona. Pedagang mulai mengeluhkan penjualan mereka turun sejak kasus Covid-19 di Indonesia. Dampak tersebut juga mengancam bagi buruh. Pekerja pabrik juga rentan tertular virus korona baru Covid-19 (Purwanto, 2020).

Selain dampak ekonomi, bidang kesehatan menjadi dampak langsung yang dirasakan oleh masyarakat. Hal tersebut diperburuk dengan keadaan kesenjangan akses terhadap pelayanan kesehatan di perdesaan dibandingkan perkotaan (Balqis, 2015). Selian itu, hasil penelitian yang dilakukan oleh Mubasyiroh et al (2018) berjudul Indeks Aksesibilitas Pelayanan Kesehatan di Indonesia seperti: 1) adanya kesenjangan dari supply tenaga dan fasilitas pelayanan kesehatan di perkotaan dan perdesaan; dan 2) terdapat kesenjangan dari faktor supply, demand, dan barrier antar perkotaan dan perdesaan, dan juga antara daerah miskin dan non-miskin. Pada penelitian tersebut dapat terlihat bahwa daerah perdesaan memiliki fasilitas kesehatan yang kurang baik dibandingkan perkotaan, sehingga berdampak pada penanganan pelayanan kesehatan yang kurang baik termasuk pada masa Covid-19. Sehingga Pemerintah perlu memperkuat sektor ekonomi dan kesehatan di wilayah perdesaan melalui Peraturan Menteri Desa, Pembangunan Daerah Tertinggal, dan Transmigrasi nomer 7 tahun 2020 tentang perubahan kedua atas peraturan Menteri Desa, Pembangunan Daerah Tertinggal, dan Transmigrasi Nomor 11 tahun 2019 tentang Prioritas Penggunaan Dana Desa Tahun 2020, Surat Edaran Nomor 8 tahun 2020 tentang Desa Tanggap Covid-19 dan Padat Karya Tunai Desa, dan Surat Edaran Nomor 4 tahun 2020 tentang Pembinaan dan Pengendalian Dana Desa Tahun Anggaran 2020. Pada beberapa peraturan tersebut melahirkan 3 program prioritas dari Pemerintah yakni Kebijakan Dana Tanggap Covid-19, Kebijakan BLT Dana Desa, dan Kebijakan Padat Karya Tunai Desa. Beberapa program prioritas tersebut bertujuan dalam penanggulangan kesehatan warga, jaringan pengaman warga miskin, dan kebangkitan ekonomi desa pada masa pandemic Covid-19.

Namun kenyataannya pemerintah masih belum efektif dalam menggunakan dana penanganan COVID-19 (Gumelar, 2020), dan masih terdapat berbagai permasalahan seperti perencanaan program dan pengelolaan anggaran dalam pembangunan desa oleh pemerintah desa (Dewan Perwakilan Rakyat Republik Indonesia, 2019; Badan Pengawasan Keuangan dan Pembangunan, 2020). Hal tersebut sesuai dengan temuan dari Khoiriyah et al (2020) tidak bisa dipungkiri bahwa suatu pemerintahan dalam melaksanakan suatu programnya terutama dalam masalah pemberian bantuan sosial yang langsung ditujukan untuk masyarakat yang membutuhkan terdapat kekurangan seperti masa Covid-19. Seperti masyarakat yang tidak mendapatkan Bantuan Langsung 
Tunai (BLT) dapat menimbulkan kecemburuan sosial. Masalah tersebut terjadi dibeberapa desa disetiap daerah, termasuk Kabupaten Lampung Selatan. Menurut Afandi (2021) pembangunan desa di Kabupaten Lampung Selatan memiliki kendala atau terhenti di tengah pandemik covid-19.

Selain itu, terdapat kurangnya kontribusi dari masyarakat dan stakeholder non-pemerintah lainnya di Lampung Selatan dalam mengerjakan program, sehingga pemerintah desa terkesan bekerja sendiri pada proses pembangunan desa masa Covid-19. Hal tersebut diungkapkan oleh Rusli bahwa "Pada kontribusi aktor lainnya dalam pembangunan desa kita contohkan pada musyawarah desa tahunan (perencanaan program), seperti biasa kami mengundang beberapa tokoh agama, tokoh masyarakat, kepala dusun, kepala RT, RW dan sebagainya. Namun belum maksimal karena masyarakat hanya ikut saja atau berfikir given. Selain itu, memang tidak mengundang swasta di dalam pelaksanaan program prioritas pembangunan desa".

Berdasarkan data tersebut diketahui bahwa pembangunan desa di Kabupaten Lampung selatan terdapat kendala, salah satu faktornya adalah Pemerintah Kabupaten Lampung Selatan kurang melibatkan stakeholder lainnya dan kurang inisiatif yang dilakukan oleh masyarakat dan swasta dalam pembangunan desa, sehingga program pembangunan desa di masa covid-19 tidak berjalan dengan baik. Hal tersebut juga dihadapi oleh beberapa desa lainnya (Redyanto et al, 2020; Oktavia \& Saharuddin, 2013; Saputra, 2018). Padahal setiap desa perlu memaksimalkan pembangunan dan pemberdayaan dari masyarakat (Rahmawati et al., 2019) atau masyarakt lokal dapat berpartisipasi dalam pengembangan desa (Ahsani et al., 2018). Oleh karena itu, perlu adanya collaborative governance didalam pembangunan desa. Menurut Ansell \& Gash (2007) Collaborative Governance didefinisikan sebagai pengaturan pemerintahan di mana satu atau lebih badan publik secara langsung melibatkan pemangku kepentingan nonpemerintahan (bisnis dan masyarakat) dalam proses pengambilan keputusan kolektif yang formal, berorientasi pada consensus dan musyawarah yang bertujuan untuk membuat atau menerapkan kebijakan publik atau mengelola program atau aset publik. Collaborative Governance merupakan salah satu cara untuk merespon keinginan para pemangku kepentingan terlibat dalam pelaksanaan pembangunan dan merespon keterbatasan pendanaan pemerintah yang tidak bisa mengikuti perkembangan tuntutan masyarakat akan kinerja pemerintah yang semakin baik dengan tujuan mendapatkan sumberdaya guna melaksanakan pembangunan sesuai harapan para pemangku kepentingan tersebut (Sambodo \& Pribadi, 2020).

\section{KAJIAN LITERATUR}

\section{Collaborative governance di Kawasan} Pedesaan.

Menurut Ansell \& Gash (2007) Collaborative Governance didefinisikan sebagai pengaturan pemerintahan di mana satu atau lebih badan publik secara langsung melibatkan pemangku kepentingan non-pemerintahan (bisnis dan masyarakat) dalam proses pengambilan keputusan kolektif yang formal, berorientasi pada consensus dan musyawarah yang bertujuan untuk membuat atau menerapkan kebijakan publik atau mengelola program atau aset publik. Menurut Innes \& Booher (2004), Collaborative Governance adalah konsep yang paling representatif dalam memahami prinsip tata kelola yang modern antara berbagai bidang governance, karena pembangunan kapasitas konsensus mampu 
mengatasi sebagian besar isu-isu kontemporer dalam masyarakat di mana warga negara berusaha mengendalikan kehidupan mereka melalui negosiasi dengan aktor lain.

Pada kaitannya dengan Administrasi Publik, collaborative governance merupakan salah satu model strategi baru dari pemerintahan yang melibatkan berbagai stakeholder atau pemangku kepentingan secara bersamaan di dalam sebuah forum dengan aparatur pemerintah untuk membuat keputusan bersama yang bertujuan untuk menyeselesaikan masalah yang tidak bisa dihadapi sendirian oleh pemerintah itu sendiri (Tilano \& Suwitri, 2019). Berdasarkan beberapa pengertian tersebut dapat di simpulkan bahwa collaborative governance merupakan kerjasama didalam tata kelola pemerintahan antara pemerintah, bisnis, dan masyarakat untuk mencapai outcome yang ditetapkan.

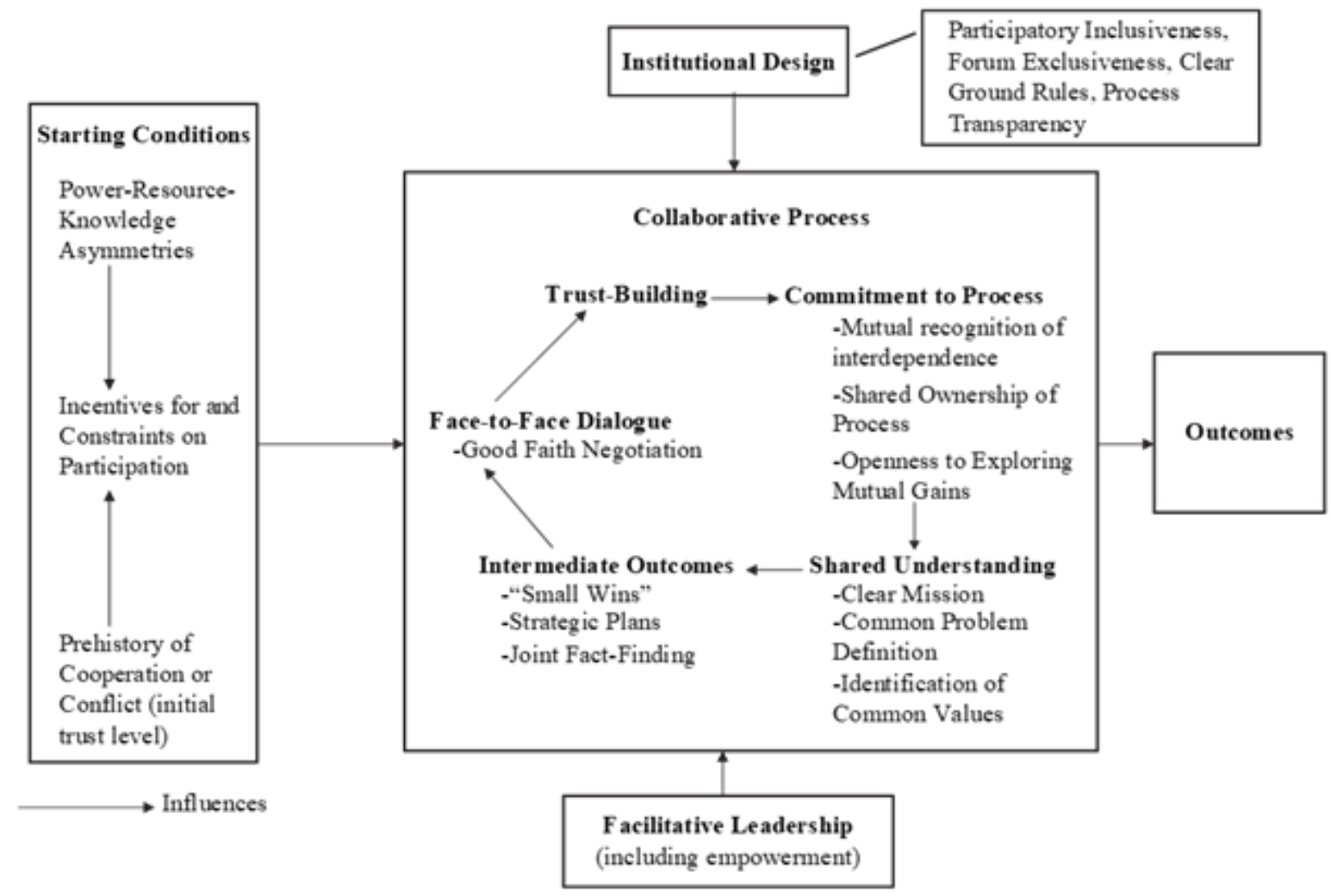

Gambar 1. Model Collaborative Governance Sumber: Ansell \& Gash, 2007

Model collaborative governance oleh Ansell dan Gash (2007) merupakan kerangka kerja yang berguna untuk memahami collaborative governance yang bekerja dalam manajemen publik. Pendekatan ini digunakan untuk menganalisis fitur dan kondisi spesifik yang diperlukan untuk kolaborasi. Model collaborative governance ini menekankan kepercayaan, visi bersama, dan timbal balik dalam kolaborasi. Selain itu, model ini sangat berguna untuk studi ini karena memilah proses kolaborasi menjadi elemen yang berbeda termasuk kondisi awal, kepemimpinan fasilitatif, desain kelembagaan, dan proses kolaboratif. Selain itu, menurut Liu et al. (2020) Model Collaborative Governance dengan pemerintah yang menyediakan platform dan memfasilitasi hubungan antara industri dan 
masyarakat. Ini bertujuan untuk mencapai inovasi yang bertanggung jawab melalui Collaborative Governance.

Model collaborative governance menurut Lieu et al., industri menyediakan produk dan layanan berkualitas tinggi, berbagi informasi terkait operasi dengan pemerintah dan terus meningkatkan desain produk dan teknologi operasi, hal tersebut tidak disebutkan didalam penelitian sebelumnya. Selanjutnya masyarakat melalui sistem kredit dan edukasi/ guidance dapat mengembangkan rasa tanggung jawab, dan meningkatkan SDM yang dapat berkontribusi pada perbaikan sistem. Benchmarking dan pengambilan keputusan bersama dapat dilakukan antara pemerintah, industri, dan masyarakat. Collaborative Governance sebagai basis pembangunan kawasan perdesaan dinilai akan mampu memaksimalkan potensi keterlibatan berbagai pihak dalam pembangunan kawasan perdesaan. Potensi untuk memajukan desa dengan mengkolaborasi sumber daya yang dimiliki berbagai pihak, dapat dimulai dengan melakukan kolaborasi pada rencana pembangunan (Febrian, 2016). Peneliti mengadopsi model Collaborative Governance dari Liu et al. (2020) dan Ansell \& Gash (2007) untuk membantu mengidentifikasi berbagai stakeholder dan kewenangannya dalam pembangunan desa

\section{Pembangunan Desa pada masa Covid-19}

Pada Undang-Undang Nomor 6 Tahun 2014 menjelaskan bahwa, pembangunan desa merupakan upaya peningkatan kualitas hidup dan kehidupan untuk sebesar-besarnya kesejahteraan masyarakat desa. Selain itu, terdapat tujuan pembangunan desa yakni meningkatkan kesejahteraan masyarakat desa dan kualitas hidup manusia serta penanggulangan kemiskinan melalui pemenuhan kebutuhan dasar, pembangunan sarana dan prasarana desa, pengembangan potensi ekonomi lokal, serta pemanfaatan sumber daya alam dan lingkungan secara berkelanjutan. Pemerintah Republik Indonesia melalui Kementerian Desa, Pembangunan Daerah Tertinggal, dan Transmigrasi Repubik Indonesia mengeluarkan Peraturan Menteri No. 2 tahun 2016 tentang Indeks Desa Membangun (IDM). Peraturan tersebut sebagai sebagai dasar rujukan (pola) pembangunan desa (Muhtarom, Kusuma, \& Purwanti, 2018; Setyobakti, 2017). IDM mengklasifikasi desa menjadi lima status yakni Desa Sangat Tertinggal, Tertinggal, Berkembang, Maju, dan Mandiri. Klasifikasi dalam lima status itu untuk mempertajam penetapan status perkembangan desa sekaligus sebagai rujukan intervensi kebijakan. IDM merupakan indikator komposit dari ketahanan sosial, ekonomi dan ekologi (Hadi, 2015; Prabowo et al., 2020).

Pada saat ini, pembangunan desa memiliki penyesuaian dalam memproritaskan program/ kegiatan. Dampak Covid-19 menjadi masalah yang harus ditangani oleh setiap pemerintah, termasuk pemerintah desa. Berdasarkan Peraturan Menteri Desa, Daerah Tertinggal, dan Transmigrasi No 7 tahun 2020 tentang Perubahan Kedua Atas Peraturan Menteri Desa, Pembangunan Daerah Tertinggal, dan Transmigrasi Nomor 11 tahun 2019 tentang Prioritas Penggunaan Dana Desa tahun 2020, Surat Edaran Nomor 4 tahun 2020 tentang Pembinaan dan Pengendalian Dana Desa Tahun Anggaran 2020, dan Surat Edaran (SE) Menteri Desa, Pembagunan Daerah Tertinggal, dan Transmigrasi No 8 Tahun 2020 tentang Desa Tanggap Covid-19 dan Penegasan Padat Karya Tunai Desa. SE ini diterbitkan pada tanggal 24 Maret 2020. SE tersebut sebagai acuan dalam pelaksanaan Desa Tanggap Covid-19 dan 
Pelaksanaan Padat Karya Tunai Desa (PKTD) dengan menggunakan dana desa, sehingga pembangunan desa menjadi upaya peningkatan kualitas hidup dan kesejahteraan masyarakat desa khususnya dalam menghadapi pandemic Covid-19.

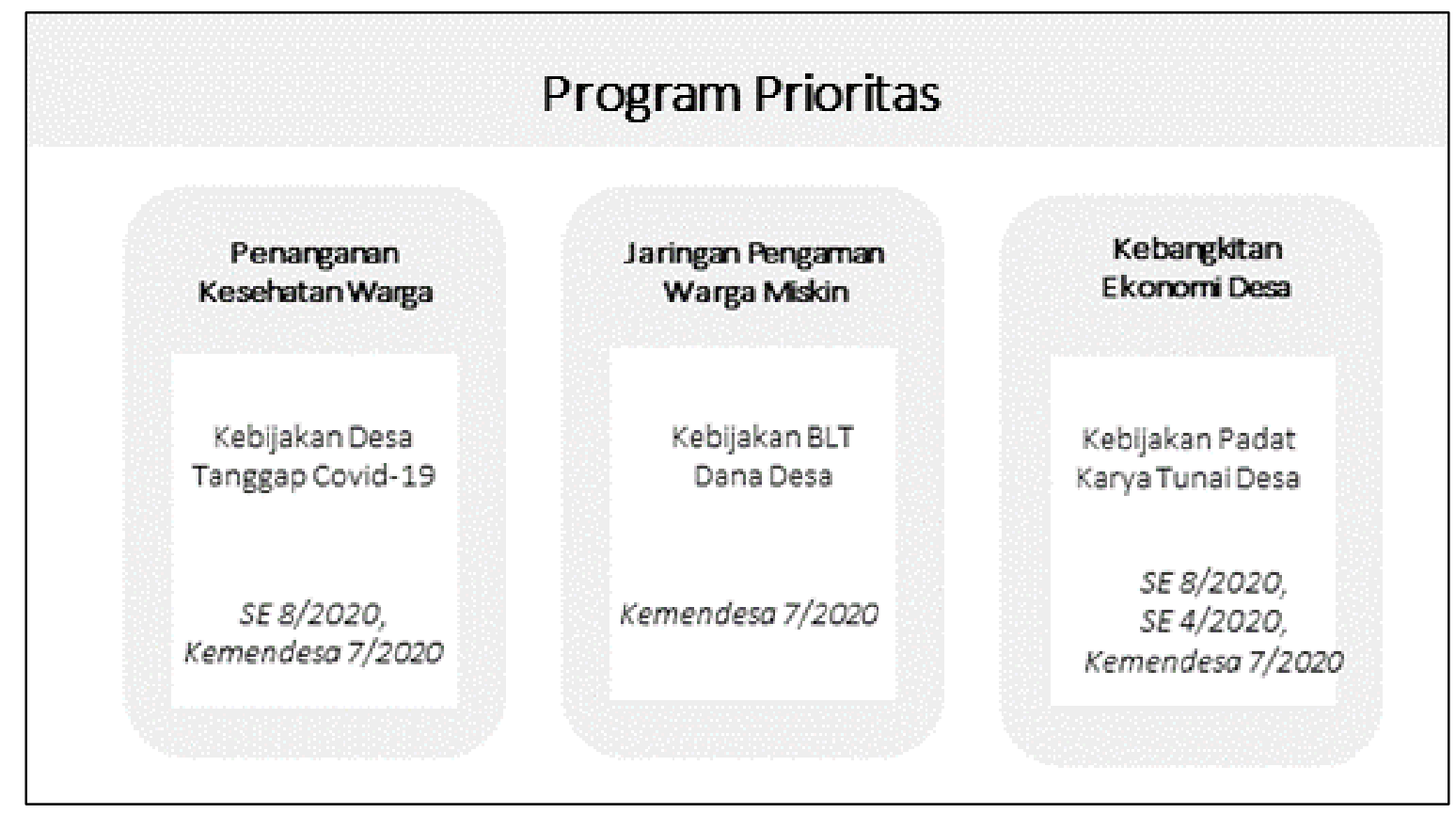

Gambar 2. Program Prioritas Pembangunan Desa 2020

Sumber: Peraturan Menteri Desa, PDTT No 7 tahun 2020, Surat Edaran No 4 tahun 2020 Surat Edaran No 8 Tahun 2020 (Diolah Peneliti, 2020).

\section{METODE PENELITIAN}

Pada Penelitian ini menggunakan pendekatan dekriptif kualitatif. Penelitian deskriptif adalah penelitian yang memberikan gambaran secara jelas dan sistematis terkait dengan objek yang diteliti. Penelitian ini juga merupakan penelitian yang memberikan informasi dan data yang sesuai dengan fenomena di lapangan (Hidayati \& Khairulyadi, 2017). Metode ini dapat juga digunakan untuk mendapatkan wawasan tentang sesuatu yang baru sedikit diketahui, serta dapat membantu peneliti memberi rincian yang kompleks tentang fenomena yang sulit diungkapkan oleh metode kuantitatif (Strauss \& Corbin, 2003). Selain itu, menurut Miles \& Huberman (1994) metode kualitatif untuk mengetahui dan menafsirkan sebuah makna dari kejadian hubungan dari satu orang dengan orang lain dalam situasi tertentu. Lokasi penelitian ini berada di Lampung selatan, sementara situs penelitian di Dinas Pemberdayaan Masyarakat dan Desa, dan Desa Siring Jaha.

Penelitian ini bersumber pada data primer dan data sekunder yakni dengan teknik pengumpulan data yang terdiri dari wawancara, observasi, dan dokumentasi. Penelitian ini terdiri dari satu informan kunci yakni Pak Rusli sebagai Kepala Desa Siring Jaha, Lampung Selatan. Informan kunci sebaiknya orang yang bersedia berbagi konsep dan pengetahuan dengan peneliti, dan sering dijadikan tempat bertanya oleh peneliti. Untuk itu sebaiknya dalam pengumpulan data peneliti sebaiknya memulainya dari informan kunci untuk mendapatkan gambaran yang utuh dan menyeluruh tentang masalah yang diamati (Martha \& Kresno, 2016). Metode wawancara pada penelitian ini adalah 
wawancara semi berstruktur, yakni wawancara dimulai dari isu yang dicakup dalam pedoman wawancara selanjutnya peneliti dapat mengembangkan pertanyaa dan memutuskan bagaimana isu dimunculkan (Rachmawati, 2007).

\section{HASIL DAN PEMBAHASAN \\ Hasil}

1) Faktor yang mempengaruhi

Starting Condition merupakan kondisi awal dimana Collaborative Governance dilaksanakan. Tahapan awal meliputi kondisi sejarah kerjasama di masa lalu, potensi, dan insentif yang diharapkan dari proses Collaborative Governance. Sejak awal ditetapkannya Desa Siring Jaha secara administrasi pada tahun 1988, Masyarakat dan Pemerintah sudah sering bekerjasama dalam melaksanakan berbagai kegiatan dari perencanaan hingga evaluasi. Kerjasama juga dilaksanakan ketika adanya pembangunan sarana prasarana umum. Selain itu tidak terdapatnya konflik dalam setiap kegiatan. Hal tersebut dijelaskan oleh Rusli bahwa:

“Dari awal terpisahnya Desa Siring Jaha dengan desa tetangga secara administrasi. Tidak pernah mengalami konflik besar, jika ada diselesaikan secara kekeluargaan dan dicari jalan keluar. Bahkan masyarakat dengan pemerintah selalu mendukung satu dengan lainnya".

Minimnya konflik dan saling bekerjasama berasal dari kebiasaan dari Desa Siring Jaha yaitu dengan menyelesaikan permasalahan dengan musyawarah dan melakukan gotong royong pada penyelesaian masalah tersebut. Selanjutnya Institutional Design merupakan forum kerjasama yang dihadiri oleh anggota, mempunyai aturan yang jelas dan proses yang terbuka. Keadaan Desa Siring Jaha dalam membangun forum ini memiliki anggota masyarakat yang berpartisipasi walaupun belum maksimal dalam forum. Selain itu, pada setiap forum melalui musyawarah mufakat bukan voting. Hal tersebut diungkapkan oleh Rusli bahwa:

"Pada musyawarah desa tahunan (perencanaan program), seperti biasa kami mengundang beberapa tokoh agama, tokoh masyarakat, kepala dusun, kepala RT, RW dan sebagainya. Namun belum maksimal karena masyarakat hanya ikut saja atau berfikir given".

Setiap melakukan forum, Pemerintah Desa Siring Jaha membentuk kepanitian yang bersifat terbuka biasanya pemerintah mengawal agar pelaksanaan kegiatan tertib secara administrasi, sedangkan masyarakat seperti tokoh agama, tokoh budaya, dan lain sebagainya berpartisipasi sebagai panitia dan peserta kegiatan, walaupun belum maksimal dalam memberikan ide pemikiran. Selain itu, Desa Siring Jaha melakukannya dengan cara transparansi mulai dari perencanaan hingga evaluasi program. Hal tersebut diungkapkan oleh Rusli bahwa:

"Kita selalu transparansi ya, dari tahapan perencanaan hingga evaluasi, bahkan kita satu-satunya desa di Kecamatan Sidomulyo yang melakukan evaluasi tiap tahun dengan mengundang semua aktor desa termasuk akan melakukan evaluasi pada bulan desember tahun ini".

Facilitative Leadership berkaitan dengan musyawarah yang dilakukan oleh stakeholder, penetapan aturan-aturan dasar yang jelas, membangun kepercayaan, memfasilitasi dialog antar stakeholder dan pembagian keuntungan bersama. Kepemimpinan fasilitatif dalam pembangunan desa dilakukan oleh Pemerintah Desa Siring Jaha. Pemerintah Desa Siring Jaha terdapat di Lampung Selatan, dimana Lampung Selatan masuk kedalam masyarakat adat Lampung Saibatin yang memiliki budaya 
kebangsawanan yang kuat (Friscilia, 2015). Sehingga Pemerintah Desa Siring Jaha sangat berpengaruh dalam keturunan bangsawan yang menjadi Kepala Desa. Selain itu, Kepala Desa sebagai pemimpin yang memiliki karisma. Pemerintah Desa Siring Jaha memiliki komitmen dalam melakukan akuntabilitas. Hal tersebut diungkapkan oleh Fitri bahwa:

"Pak Lurah saat ini bagus dan punya 'trah' atau karisma sebagai pemimpin, selain itu memang dulu Ayahnya Pak Lurah sebagai Kepala Desa pertama Desa Siring Jaha tahun 1988"

\section{2) Proses Collaborative Governance}

Face to face dialog atau pertemuan tatap muka merupakan pertemuan antara berbagai pihak dalam satu lokasi dan dalam waktu yang sama sehingga terjadi dialog secara langsung atau interaktif antara berbagai pihak tersebut, untuk membahas suatu kepentingan bersama. Dialog secara langsung di Desa Siring Jaha sudah terlembaga dengan baik. Bentuk face to face dialog yang dilakukan oleh Desa Siring Jaha antara lain rapat. Rapat tersebut Musyawarah Desa, Musyawarah Dusun, Musyawarah Lembaga, dan rapat yang dilakukan formal lainnya. Rapat-rapat ini bersifat dapat dihadiri oleh semua masyarakat dan/atau dengan masyarakat terbatas. Namun semua rapat-rapat tersebut bersifat musyawarah mufakat. Hal tersebut diungkapkan oleh Rusli bahwa:

“Desa Siring Jaha melakukan beberapa rapat yang bersifat terbuka umum dan terbatas. Ada rapat yang dilakukan oleh beberapa orang dengan terbatas karena beberapa hal tidak perlu dilakukan dengan banyak orang. Namun ada rapat bersifat umum semua orang dapat berpartisipasi, biasanya sesuai pengaruh dari topik rapat tersebut"
Trust building atau membangun kepercayaan merupakan strategi manajemen tidak hanya fokus pada saat ini, tapi juga kerja sama akan datang. Membangun kepercayaan mempunyai niatan yang sama untuk mengambil kebijakan yang terbaik untuk semua Pihak. Trust Building dimulai dengan dengan membangun komunikasi antar berbagai pihak yang terlibat dalam Desa Siring Jaha. Membangun kepercayaan di Desa Siring Jaha sudah dilakukan bertahun-tahun sebelumnya. Biasanya untuk menjaga agar ada pertemuan berkala setiap saat. Di dalam pertemuan rapat tersebut sebagai sarana menginformasikan hal penting dan warga juga di beri waktu untuk mengemukakan pendapatnya pada sesi selanjutnya. Keterbukaan informasi ini menjadi kunci untuk membina kepercayaan. Dan hal pokok lainnya adalah komitmen Pemerintah Desa untuk transparan dan bertanggungjawab. Pemerintah Desa selalu melibatkan lembaga kemasyarakatan dalam suatu kepanitian kegiatan dalam membangun Desa Budaya.

Comitment to Process merupakan komitmen atau kesepakatan untuk melaksanakan suatu proses tertentu guna mencapai tujuan bersama yang diinginkan. Saling berbagi komitmen, berarti Mereka saling tergantung satu sama lain untuk mengatasi permasalahan dan solusi, bahwa proses ini merupakan milik bersama, dan Saling terbuka untuk mendapatkan manfaat bersama. Sedangkan Share understanding atau pemahaman bersama adalah mengetahui aturan, tujuan, dan batasan pengejaran. Hal tersebut merupakan aturan mainnya untuk diketahui oleh setiap aktor yang terlibat. Pemahaman bersama adalah keadaan yang diturunkan hasil dari musyawarah, tidak diserahkan pada pemikiran yang tidak disengaja dan anganangan. Berbagai pengertian dan 
pemahaman sudah diupayakan oleh Pemerintah Desa Siring Jaha, masyarakat, dan aktor swasta pada beberapa kegiatan. Pemerintah Desa selalu berupaya untuk menjalin komunikasi dan memberikan informasi kepada masyarakat dan aktor lainnya secara timbal balik juga meminta masukan.

Intermediate outcome merupakan hasil sementara atas proses yang sedang berlangsung. Hasil sementara tersebut sudah memberikan manfaat dan bernilai strategis. Desa Siring Jaha sudah melakukan beberapa hal saat ini seperti terlaksananya seperti: 1) Program desa tanggap covid-19 dengan membentuk panitia tanggap covid19, melakukan penyemprotan disinfektan rutin, membentuk ruang isolasi, dan sebagainya; 2) Program Bantuan Langsung Tunai Dana Desa, program ini menggunakan 20-30\% dari Dana Desa yang diperuntukan bagi masyarakat kurang mampu di Desa Siring Jaha; 3) Padat Karya Tunai Desa, pada program ini Pemerintah Desa memberikan sebuah pekerjaan yang diperuntuhkan bagi masyarakat Desa Siring Jaha. Terdapat beberapa kegiatan pembangunan seperti pembentukan tempat pembuangan akhir (TPA), Sanggar Seni, dan lainnya yang menggunakan tenaga masyarakat Desa Siring Jaha; dan 4) Pembangunan lainnya contohnya program ternak sapi dan program Jasa Brilink. Pada beberapa program sersebut, hasil sementara yang mulai bisa dimanfaatkan oleh masyarakat seperti bantuan uang tunai, kesehatan, dan sebaginya.

3) Aktor yang terlibat didalam Pembangunan Desa

Pemerintah Desa dalam menyikapi dampak Covid-19, memiliki penyesuaian dalam pembangunan desa dengan memproritaskan beberapa program/ kegiatan sesuai arahan Kementerian Desa, Daerah Tertinggal, Transmigrasi melalui beberapa peraturannya seperti Peraturan Menteri Desa, Daerah Tertinggal, dan Transmigrasi No 7 tahun 2020, Surat Edaran No 4 tahun 2020, dan Surat Edaran No 8 Tahun 2020. Pada peraturan tersebut memprioritaskan Program Desa Tanggap Covid-19 (DTC), Program Bantuan Langsung Tunai Dana Desa (BLT), Padat Karya Tunai Desa (PKTD), dan Pembangunan lainnya. Berdasarkan beberapa program tersebut terjadi beberapa kerjasama dengan beberapa aktor, dapat dilihat di Tabel 1. sebagai berikut.

Tabel 1. Stakeholder dalam Pembangunan Desa di Desa Siring Jaha, Kabupaten Lampung Selatan

\begin{tabular}{lllll}
\hline \multirow{2}{*}{ Aktor } & \multicolumn{4}{l}{ Program-program Pembangunan Desa } \\
\cline { 2 - 4 } & \multicolumn{3}{l}{ Program Prioritas } & \multicolumn{3}{l}{ Program Lainnya } \\
\cline { 2 - 4 } & DTC & BLT & PKTD & \\
\hline Pemerintah Desa & $\checkmark$ & $\checkmark$ & $\checkmark$ & $\checkmark$ \\
\hline Bisnis/ Swasta & - & - & - & $\checkmark$ \\
\hline Masyarakat Desa & $\checkmark$ & $\checkmark$ & $\checkmark$ & $\checkmark$ \\
\hline
\end{tabular}

Berdasarkan tabel tersebut, bahwa program-program pembangunan desa di Siring Jaha dilakukan dengan partisipasi beberapa aktor. Seperti pada program prioritas seperti Desa Tanggap Covid-19, Bantuan Langsung Tunai Dana Desa, dan
Padat Karya Tunai Desa dilakukan oleh Pemerintah Desa Siring Jaha dengan Masyarakat Desa. Disisi lain pada program pembangunan lainnya terdapat kerjasama dengan pihak swasta seperti contohnya pada program ternak sapi dan program Jasa 
Brilink. Pada program ternak sapi, pemerintah Desa Siring Jaha melakukan kerjasama dengan PT Juang Jaya Abadi Alam dan beberapa Doktor Hewan. Kerjasama ini melibatkan masyarakat sebanyak 32 orang. Sedangkan pada progam Jasa Brilink dilakukan antara Badan Usaha Milik Desa (BUMDes) Desa Siring Jaha dengan PT Bank Rakyat Indonesia (BRI). Hal tersebut diungkapkan oleh Rusli bahwa:

“Desa Siring Jaha melakukan kerjasama dengan PT Juang Jaya Abadi dalam hal

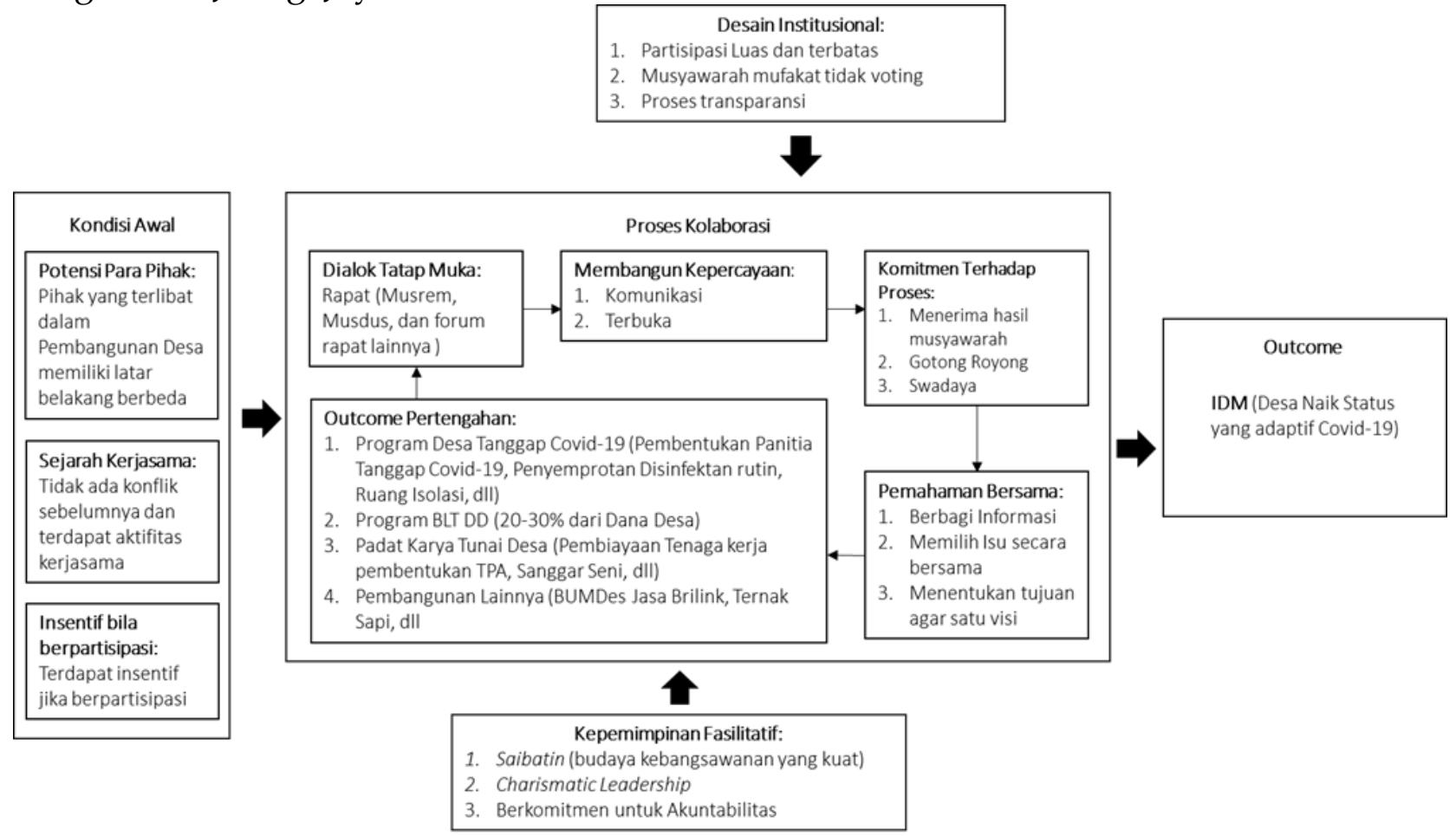

ketahanan pangan, jadi kami diberikan beberapa ekor sapi oleh PT Juang setelah itu dilakukan pembagian jika sudah beranak. Selain itu, BUMDes sudah berjalan salah satunya kami menyedikan jasa transfer dengan BRI"

Berdasarkan beberapa data yang terlampir sebelumnya dan merujuk pada Model Collaborative Governance (Ansel \& Gash, 2007), Collaborative Governance di Desa Siring Jaha adalah sebagai berikut:

Gambar 3. Hasil Collaborative Governance dalam Pembangunan Desa

\section{Pembahasan}

Secara umum didapatkan beberapa permasalahan dalam pembangunan desa di Desa Siring Jaha. Gejala umum yang terjadi adalah masih lemahnya kerjasama antar aktor yang terlibat sehingga menyebabkan implementasi program tidak berjalan sesuai kebutuhan masyarakat atau stakeholder non-pemerintah lainnya. Proses perencanaan tidak dilakukan dengan pelibatan masyarakat secara optimal. Untuk itu diperlukan upaya penguatan kelembagaan dengan berbasis pada collaborative governance. Selanjutnya pembahasan mengenai model collaborative governance yang ideal dalam pembangunan desa pada masa covid-19. Model Collaborative Governance terkadang menggambarkan perkembangan kolaborasi secara bertahap (Ansel \& Gash, 2007). Collaborative Governance terletak dalam dinamika konteks sistem yang dapat 
mencakup sumber daya, kebijakan dan kerangka hukum, sosial ekonomi dan karakteristik budaya, karakteristik jaringan, dinamika politik dan hubungan kekuasaan dan sejarah konflik, di antara dimensi lainnya (Emerson \& Nabatchi, 2015). Secara khusus, jaringan (hubungan) yang sudah terbangun sebelumnya serta konteks kelembagaan penting karena mereka membentuk peluang dan kendala, dan memengaruhi if, how and when dari collaborative governance dibuka dan dijalankan (Bryson et al., 2015; Sandfort \& Moulton, 2014; Dickinson \& Glasby, 2010; McGUIRE \& Agranoff, 2011).

Pada gambar 4, peneliti menghasilkan model collaborative governance 'egg' sebagai pengembangan dari Ansel \& Gash (2007) dan Liu et al. (2020). Mengusulkan model collaborative governance ini dengan pemerintah menyediakan platform dan memfasilitasi aliansi antara swasta (industri) dan masyarakat. Ini bertujuan untuk mencapai inovasi yang bertanggung jawab melalui tata kelola pemerintahan yang kolaboratif. Dalam kerangka ini, industri terutama menyediakan produk dan layanan berkualitas tinggi, berbagi informasi terkait operasi dengan pemerintah dan terus meningkatkan desain produk dan teknologi. Sehingga pengambilan keputusan bersama dapat dilakukan antara pemerintah, industri, dan masyarakat. Berdasarkan model collaborative governance 'egg' terdapat dua lapisan. Lapisan pertama sebagai 'eggshells' pada lapisan ini terdapat interaksi khusus antara pemerintah dengan swasta, pemerintah dengan masyarakat, dan masyarakat dengan swasta. Pada lapisan ini mengadopsi dari Liu et al. (2020). Pemerintah dengan swasta atau
Government to business merupakan adalah istilah yang mengacu pada hubungan antara organisasi pemerintah dan swasta atau bisnis (Stancic et al., 2017). Pemerintah dan swasta dapat mengembangkan produk berupa teknologi atau non-teknologi (Liu et al., 2020), produk tersebut dapat digunakan untuk memudahkan pembangunan desa. Selanjutnya swasta dengan masyarakat atau Business to Society merupakan hubungan kerjasama yang dilakukan oleh swasta dengan masyarakat. Hubungan kerjasama ini berupa improvement produk dan pelayanan (continuous improvement) atau meningkatkan kualitas produk dan jasa kepada masyarakat. Pentingnya kegiatan ini dilakukan pihak swasta agar produk dan jasa dapat memberikan kebermanfaatan pada masa pandemi. Sedangkan hubungan Pemerintah dengan masyarakat memiliki dua kegiatan yang diperlukan yakni feedback platform dan edukasi. Pentingnya membentuk platform timbal balik dari masyarakat ke pemerintah supaya masyarakat sebagai penerima program dapat memberikan masukan kepada pemerintah dalam rangka perbaikan. Kegiatan edukasi atau guidance diperlukan didalam menuntun masyarakat yang memiliki keterbatasan informasi. Peran dari guidance sangat diperlukan untuk masyarakat yang memiliki kesulitan/ keterbatasan dalam memahami pembangunan desa (Rakhmawati \& Purwasih, 2018; Indrianrtiningtias \& Mafrufah, 2012). Secara khusus, pada 'eggshells' berfokus pada hubungan antara bisnis, masyarakat, dan pemerintah saling ketergantungan dan keterkaitan dari ketiga entitas tersebut (Lussier \& Sherman, 2009; Steiner \& Steiner, 2006). 


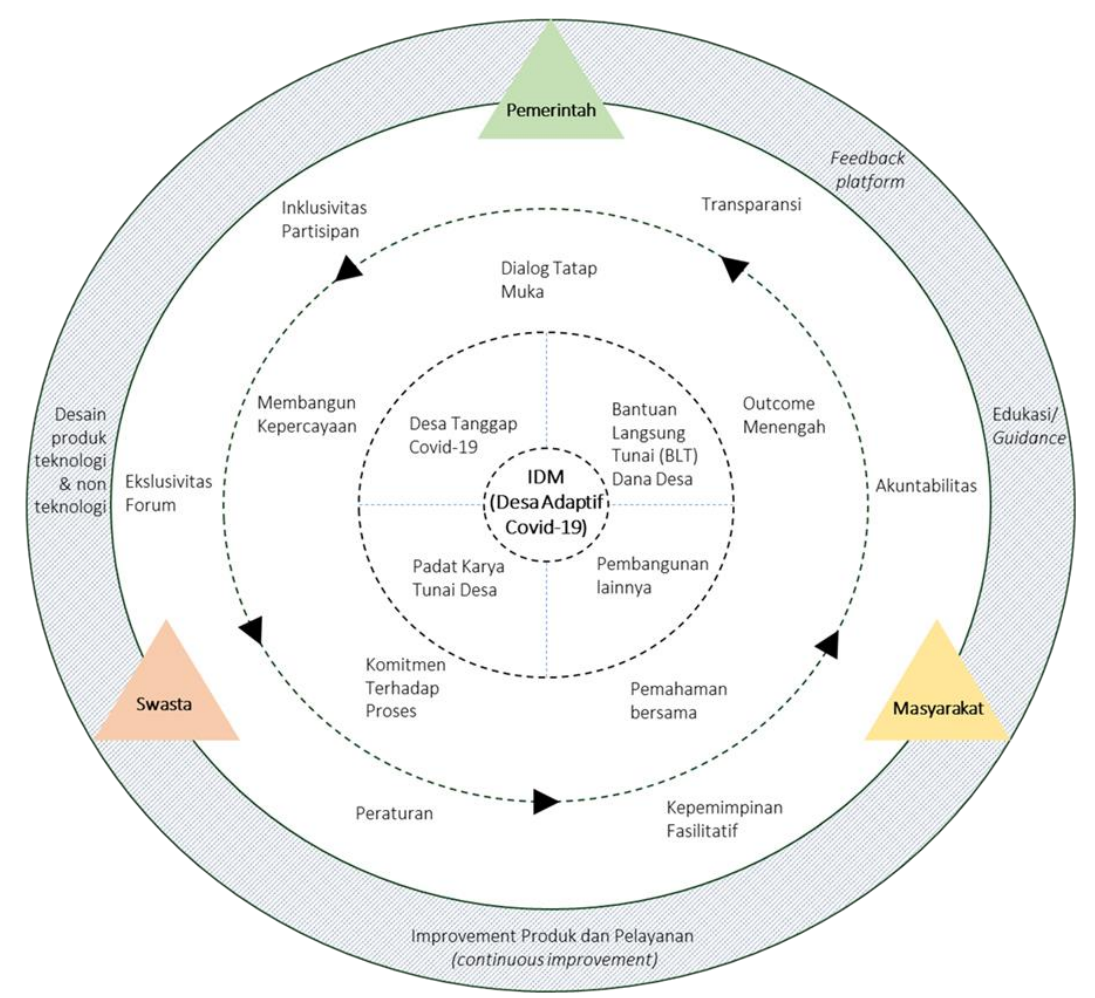

Gambar 4. Pengembangan model Collaborative Governance 'egg' dalam Pembangunan Desa pada Pandemik Covid-19

Setelah lapisan 'eggshells', peneliti mengadopsi Ansel \& Gash (2007) di lapisan dalam diawali prinsip kolaborasi yang terdiri dari kepemimpinan fasilitatif, penetapan aturan-aturan dasar yang jelas, membangun kepercayaan, memfasilitasi dialog antar stakeholders dan pembagian keuntungan bersama, tata cara dan peraturan dasar dalam kolaborasi untuk prosedural proses kolaborasi yang legal, transparansi proses, inklusivitas partisipan, eksklusivitas forum, dan akuntabilitas. Pada prinsip kolaborasi ini khususnya akuntabilitas, perlu adanya keterlibatan semua stakeholder di desa. Temuan dari penelitian ini, pemerintah belum melakukan keterlibatan semua segmentasi aktor. Karena keterlibatan masyarakat dan pemerintah desa saja belum cukup untuk memenuhi kebutuhan pembangunan pedesaan. Sehingga pada model ini diperlukannya keterlibatan semua stakeholder Menurut Zeho et al. (2020) keterlibatan stakeholder yang terbatas menyebabkan proses akuntabilitas tidak berjalan mulus. Pelibatan pemangku kepentingan eksternal atau lebih luas harus segera dilaksanakan untuk memainkan peran penting dalam membantu pemerintah desa dalam menjalankan tugas dan fungsinya untuk menjadi desa yang mandiri.

Selanjutnya masuk ketahap proses kerjasama, pada tahap ini perlu dilakukannya beberapa hal diawali dialog tatap muka, membangun kepercayaan, membangun komitmen terhadap proses, membangun pemahaman bersama, selanjutnya mengukur outcome menengah atau hasil sementara yang didapatkan. Pada proses ini, menghasilkan beberapa program prioritas berdasarkan Peraturan Menteri Desa, Daerah Tertinggal, dan Transmigrasi No 7 tahun 2020 tentang Perubahan Kedua Atas Peraturan Menteri Desa, Pembangunan Daerah Tertinggal, dan 
Transmigrasi Nomor 11 tahun 2019 tentang Prioritas Penggunaan Dana Desa tahun 2020, Surat Edaran Nomor 4 tahun 2020 tentang Pembinaan dan Pengendalian Dana Desa Tahun Anggaran 2020, dan Surat Edaran Menteri Desa, Pembagunan Daerah Tertinggal, dan Transmigrasi No 8 Tahun 2020 tentang Desa Tanggap Covid-19 dan Penegasan Padat Karya Tunai Desa.

Terdapat 3 program prioritas yakni Desa Tanggap Covid-19, Padat Karya Tunai Desa, dan Bantuan Langsung Tunai Dana Desa, serta Program Pembangunan dukungan lainnya menjadi program yang perlu dilakukan oleh Pemerintah, Swasta, dan Masyarakat sesuai dengan porsi kewenangan mereka masing-masing, sehingga desa dituntut memiliki kemampuan dan kualitas sumber daya manusia untuk mengelola sumber daya desanya dengan baik (Zeho et al. 2020). Pada proses collaborative governance ini bertujuan untuk mencapai Indeks Desa Membangun yakni Desa Naik Status yang adaptif Covid19. Menurut Ansell \& Gash (2007) memperkirakan bahwa permintaan untuk kerjasama dan koordinasi yang lebih baik antara pemerintah dan pemangku kepentingan tidak akan berkurang dalam waktu dekat. Selain itu, konsep Collaborative Governance dinilai sejalan dengan pembangunan kawasan perdesaan yang substansinya memerlukan keterlibatan beberapa pihak bukan hanya pemerintah desa untuk percepatan pembangunan, pelayanan dan pemeberdayaan masyarakat desa (Febrian, 2016).

\section{PENUTUP}

Penelitian ini membahas peran kebijakan pemerintah dalam konteks ekonomi dan kesehatan di masa pandemi, untuk mencapai inovasi yang bertanggung jawab. Sehingga peneliti menyarankan model Collaborative Governance 'egg' dengan memaksimalkan peran pemerintah desa dalam menyediakan platform dan memfasilitasi aliansi antara swasta dan masyarakat yang bertujuan untuk mencapai inovasi yang bertanggung jawab melalui tata kelola pemerintahan yang kolaboratif. Hal tersebut terjadi karena masih lemahnya kerjasama antar aktor yang terlibat sehingga menyebabkan implementasi program tidak berjalan sesuai kebutuhan masyarakat atau stakeholder non-pemerintah lainnya seperti masyarakat dan bisnis. Proses perencanaan tidak dilakukan dengan pelibatan masyarakat secara optimal. Selain itu, model ini sebagai model yang dapat dilakukan oleh setiap pemerintah desa dalam memaksimalkan kerjasama pada setiap program pembangunan desa masa Covid19.

Tujuan dari model collaborative governance ini untuk menaikan Status Desa dengan mengadaptasikan masa pandemic Covid-19. Sesuai dengan Peraturan Kementerian Desa, Pembangunan Daerah Tertinggal, dan Transmigrasi Nomer 2 tahun 2016 tentang Indeks Desa Membangunan. Pembangunan kawasan perdesaan secara Collaborative Governance, ditujukan untuk mempercepat proses peningkatan kesejahteraan masyarakat di era pandemi.

\section{DAFTAR PUSTAKA}

Afandi, Muhammad. (2021). Efektifitas Program BUMDes dalam Pemberdayaan Ekonomi Masyarakat ditinjau dari Manajemen Bisnis Islam (Studi Kasus Desa Gantiwarno Pekalongan Lampung Timur). Tesis Fakultas Ekonomi dan Bisnis Isalam, IAIN Metro.

Ahsani, Retno D. P., Suyaningsih, O., Ma'arifah, N. \& Aerani, E. (2018). Penerapan Konsep Community Based Tourism (CBT) di Desa Wisata 
Candirejo Borobudur Mewujudkan Kemandirian Desa. PUBLISIA: Jurnal Ilmu Adminitrasi Publik, Vol. 3, No. 2.

Amindoni, Ayomi. (2020). Virus corona: Gelombang PHK di tengah pandemi Covid-19 diperkirakan mencapai puncak bulan Juni, Kartu Prakerja dianggap tak efektif. Diakses pada pukul 21.00 WIB tanggal 21 November 2020 melalui Virus corona: Gelombang PHK di tengah pandemi Covid-19 diperkirakan mencapai puncak bulan Juni, Kartu Prakerja dianggap tak efektif - BBC News Indonesia

Ansell, C. \& Gash, A. (2007). Collaborative Governance in Theory and Practice. Journal of Public Administration Research and Theory, 18, 543-571. doi:10.1093/jopart/mum032

Badan Pengawasan Keuangan dan Pembangunan. (2020). Pengawalan Akuntabilitas Keuangan Desa. Diakses pada pukul 23.28 WIB WIB tanggal 1 Desember 2020 melalui http://www.bpkp.go.id/sulbar/ber ita/read/23902/75/

Balqis. (2015). Kesenjangan Kesehatan di Daerah Tertinggal. Diakses pada pukul 8.50 WIB WIB tanggal 29 Maret 2020 melalui https:/ / makassar.tribunnews.com/2 015/11/12/kesenjangan-kesehatandi-daerah-tertinggal

Bryson, J. M., Crosby, B. C., \& Stone, M. M. (2015). Designing and strategically managing crosssector collaborations John M. Bryson: The Us-India Relationship.

Dewan Perwakilan Rakyat Republik Indonesia. (2019). Pengelolaan Dana Desa Masih Bermasalah. Diakses pada pukul 23.03 WIB WIB tanggal 1 Desember $2020 \quad$ melalui http://www.dpr.go.id/berita/detail /id/25283/t/Pengelolaan+Dana+De sa+Masih+Bermasalah

Dickinson, H., \& Glasby, J. (2010). 'Why partnership working doesn't work' pitfalls, problems and possibilities in english health and social care. Public Manage Rev, 12, 811-28.

Emerson, K. \& Nabatchi, T. (2015). Collaborative governance regimes. Georgetown: Georgetown University Press.

Febrian, Ranggi A. (2016). Collaborative Governance dalam Pembangunan Kawasan Perdesaan (Tinjauan Konsep dan Regulasi). WEDANA: Jurnal Pemerintahan, Politik, dan Birokrasi, 2(1), 200-208.

Friscilia, Fikha. (2015). Adat di Masyarakat Lampung Saibatin. Diakses pada pukul 00.01 WIB WIB tanggal 2 Desember $2020 \quad$ melalui http:// malahayati.ac.id/?p=15335

Gumelar, G. (2020). Agar Dana Desa Tak Sekadar Jadi Gimik Politik. Diakses pada pukul 23.00 WIB WIB tanggal 21 Novermber 2020 melalui Agar Dana Desa Tak Sekadar Jadi Gimik Politik (cnnindonesia.com)

Hadi, Sofwan. (2015). Indeks Desa Membangundan Pembangunan Desa. Website Sekolah Desa: Sekolah Pembaharuan Desa 2015. Diakses pada tanggal 8 Desember 2019 pukul 20.31 WIB melalui https://sekolahdesa.or.id/indeksdesa-membangun-danpembangunan-desa/

Hidayati, Nurul. \& Khairulyadi. (2017). Upaya Institusi Sosial dalam Menganggulangi Pengemis Anak di Kota Banda Aceh (Studi terhadap institusi formal dinas sosial dan tenaga kerja di Kota Banda Aceh). 
Jurnal Ilmiah Mahasiswa FISIP Unsyiah, 2(2), 737-764.

Indrianrtiningtias, R. \& Mafrufah, I. (2012). Analisis Pengaruh Transfer Pengetahuan Terhadap Kelompok Tani Pengolah Salak Di Bangkalan. Prosiding Seminas.

Innes, Judith E. \& Booher, David E. (2004). Reframing public participation: Strategies for the $21^{\text {st }}$ century. Planning Theory and Practice, 5(4), 419-436.

Iswara, Made A. (2020). 1.2 million Indonesian workers furloughed, laid off as COVID-19 crushes economy. Diakses pada pukul 22.30 WIB WIB tanggal 1 Desember 2020 melalui https:/ / www.thejakartapost.com/n ews/2020/04/09/worker-welfareat-stake-as-covid-19-wipes-outincomes.html.

Khoiriyah, F., Oktavia, L., et al. (2020). Efektivitas Pelaksanaan Bantuan Sosial Dari Pemerintah Terhadap Masyarakat Terdampak Covid-19 Di Desa Gendongarum Kecamatan Kanor Kabupaten Bojonegoro. Jurnal Spirit Publik, Volume 15, Nomor 2, Hal. 97-110.

Liu, Z. Ma, L. Huang, T. \& Tang, H. (2020). Collaborative Governance for Responsible Innovation in the Context of Sharing Economy: Studies on the Shared Bicycle Sector in China. Journal of Open Innovation: Technology, Market, and Complexity, 6 (2). Doi: 10.3390/joitmc6020035

Lussier, R. and Sherman, H. (2009). Business, Society and Government Essentials, Long Grove, Illinois: Waveland Press.

Martha, E., \& Kresno, S. (2016). Metodologi Penelitian Kualitatif. Jakarta: Rajawali Press.

P-JIAP: Vol. 6 (1) 2021
McGUIRE, M., \& Agranoff, R. (2011). The limitations of public management networks. Public Adm 89, 265-84.

Miles, M. B., \& Huberman, A. M. (1994). Qualitative data analysis: An expanded sourcebook (2nd ed.). USA: Sage Publications, Inc.

Mubasyiroh, R., Nurhotimah, E., \& Laksono, Agung D. (2018). Indeks Aksesibilitas Pelayanan Kesehatan di Indonesia. Diakses pada pukul 18.30 WIB WIB tanggal 29 Maret 2020 melalui https://www.researchgate.net/p ublication/326439183

Muhtarom. Kusuma, N. \& Purwanti, E. (2018). Analisis Indeks Desa Membangun Untuk Mengetahui Pola Perkembangan Pembangunan Desa Di Kecamatan Gadingrejo Kabupaten Pringsewu. Inovasi Pembangunan: Journal Balibangda Lampung. Vol. 06, No. 2, Hal. 179-190.

Oktavia, S. \& Saharuddin. (2013). The Relationship between Role of the Stakeholders and Community participation in Agropolitan Program in Karacak Village, Leuwiliang Subdistrict, Bogor District. Sodality: Jurnal Sosiologi Pedesaan, 1(3), 231246.

Prabowo, Ardian. Muluk, Khairul M. R. \& Hayat, A. (2020). Alternatif Kebijakan Keterbatasan Aksesibilitas Perpustakaan di Kabupaten Malang. MATRA PEMBARUAN: Jurnal Inovasi Kebijakan, 4(2), 119-133.

Purwanto, A. (2020). Dunia Usaha dan Pekerja Dibayangi Korona. Diakses pada pukul 21.02 WIB tanggal 29 Maret $2020 \quad$ melalui https://kompas.id/baca/riset/2020 /03/25/dunia-usaha-dan-pekerjadibayangi-korona/ 
Rachmawati, Imami N. (2007). Pengumpulan data dalam penelitian kualitatif: wawancara. Jurnal Keperawatan Indonesia, Vol. 11, No. 1, Hal. 35-40.

Rahmawati, A., Hendrarto, Ahsani, Retno D. P. (2019). Manajemen Dana Desa di Desa Girirejo Kecamatan Kaliangrik, Kabupaten Magelang Tahun 2018. PUBLISIA: Jurnal Ilmu Administrasi Publik, Vol. 4, No. 2, Hal. 149-156.

Rakhmawati, L. \& Purwasih, G. D. (2018). Peranan Bimbingan dan Penyuluhan dalam Menanggulangi Kesulitan Belajar Siswa. MODELING: Jurnal Program Studi PGMI 5(1), 39-56

Redyanto, Fandri W. Salahudin. \& Salviana, V. (2020). Model Collaborative Governance Pemerintahan Daerah dan Masyarakat dalam Pengaelolaan Pantai Duta di Kabupaten Probolinggo. Theisis Universitas Muhammadyah Malang.

Sambodo, Giat T. \& Pribadi, U. (2016). Pelaksanaan Collaborative Governance di Desa Budaya Brosot, Galur, Kulonprogo, DI. Yogyakarta. Jurnal Ilmu Pemerintahan \& Kebijakan Publik, 3(1), 94-123. http://dx.doi.org/10.18196/ jgpp.2016.0052

Sandfort, J., \& Moulton, S. (2014). Effective implementation in practice: Integrating public policy and management. USA: John Wiley \& Sons

Saputra, Febri Setiawan E. (2018). Analisis Keterlibatan Stakeholder dalam Program Desa Broadband Terpadu di Desa Karangmojo Kecamatan Karangmojo dan Desa Putat Kecamatan Patuk Kabupaten Gunung Kidul Daerah Istimewa
Yogyakarta. Thesis Universitas Islam Indonesia.

Setyobakti, M. Hudi. 2017. Identifikasi Masalah dan Potensi Desa Berbasis Indeks Desa Membangun (IDM) di Desa Gondowangi Kecamatan Wagir Kabupaten Malang. WIGA: Jurnal Penelitian Ilmu Ekonomi. Vol. 7, Hal. 1-14.

Stancic, H. Ivanjko, T. \& Garic, A. (2017). Government to Business E-Services Accountability and Trust. Tidsskriftet Arkiv, 8-1. DOI: http://dx.doi.org/10.7577/ta.1958

Steiner, G. \& Steiner, R. (2006). Business, Government, and Society. Boston: McGraw-Hill, Irwin.

Strauss, Anselm. \& Corbin, Juliet. (2003). Dasar-dasar Penelitian Kualitatif. Yogjakarta: pustaka Pelajar.

The Center for Systems Science and Engineering Johns Hopkins University. (2020). Covid-19. Diakses pada pukul 22.21 WIB tanggal 21 November $2020 \quad$ melalui https:// coronavirus.jhu.edu

Tilano, Fawwaz A. \& Suwitri, S. (2019). Collaborative Governance in an Effort to Traffic and Road Transportation Safety in Semarang City. Jurnal of Public Policy and Management Review, 8(3), 1-18. DOI: 10.14710/jppmr.v8i3.24039

World Bank. (2020). World Bank Group Increases COVID-19 Response to \$14 Billion To Help Sustain Economies, Protect Jobs. Press Release. Diakses pada pukul 12.23 WIB tanggal 29 Maret $2020 \quad$ melalui https://www.worldbank.org/en/ne ws/pressrelease/ 2020/03/17/world-bank-groupincreases-covid-19-response-to-14billion-tohelp- sustain-economiesprotect-jobs 
Zeho, F. H., Prabowo, A., Estiningtyas, R. A., Mahadiansar, \& Sentanu, I. G. E. P. S. (2020). Stakeholder collaboration to support accountability in village fund management and rural development.
Journal of Socioeconomics and Development, 3(2), 89-100. https://doi.org/10.31328/jsed.v3i2.1 395 